\title{
Phenotypic characterization of Cashmere goats in Western Mongolia
}

\author{
Sergelen Baldan, Bayarjargal Manaljav, Badam Battulga, Odgerel Nergui, Ariunzaya Enkhtuya, \\ Batgerel Davaakhuu, Narantuya Baatar, Myagmarsuren Purevdorj"-ⓘ
}

Animal Science Sector, Research Institute of Animal Husbandry, Mongolian University of Life Sciences, Zaisan 17024, Ulaanbaatar, Mongolia

*Corresponding author: myagmarsuren0224@gmail.com

https://orcid.org/0000-0001-6694-7342

\begin{tabular}{lll}
\hline Received: 30.03 .2021 & Revised: 25.06 .2021 & Accepted: 15.09 .2021
\end{tabular}

\begin{abstract}
This study was conducted as a preliminary study to design the breeding activity of Mongolian cashmere goats. To characterize the phenotypic traits of goats in Western Mongolia, the linear body measurements and cashmere yield and its the quality were measured. In this study, 608 cashmere goats were selected from the areas where it highly affected to overgrazing and overstocked in this area. The study used a random sampling method from the populations. The normality of the data was checked using the Shapiro-Wilk normality test and analyzed using the linear model procedure in R software. All male (buck) and female goats had straight head profiles (100\%). Black coat color was predominant in Erdeneburen, Bayan-Uul soums and all of the goats in Ulgii soum were red. The goats in Ulgii soum were the biggest in body size compared to Erdeneburen and Bayan-Uul in Ulgii soums. The goats had back horn orientation $(100 \%)$. Significant effects ( $\mathrm{p}<0.001)$ of sex, age, locations, and sex*age classes were observed on live body weight, cashmere quantitative and qualitative characteristics, and linear body measurements.
\end{abstract}

Keywords: Cashmere goats, live body weight, linear body measurements, cashmere characteristics, variations

\section{Introduction}

Goats are raised for multipurpose in the country providing meat, milk, cashmere, and skin. Over the past three decades, the economic importance of cashmere outweighed meat and milk in accordance with increased cashmere demand at the international market. During 1997-1998, cashmere income presented on average $28.1 \%$ of herders' income [1]. In 10 years, herders in the western region gained as much as $75 \%$ of their income from cashmere sales [2]. Yet, the reputation of Mongolian cashmere has been hindered by its coarsened fibre diameter and deteriorated pasture condition in recent years. The coarsened fibre was due to the increased number of adult male goats in the flock which yield much more in volume than females and young males but coarser in diameter [3]. Historically, the cashmere fibre diameter of indigenous goats was noted to be 14.8 $\mu \mathrm{m}$ on average [4]. However, studies showed that among known breeds cashmere yield was increased by $6.3-60.8$ percent, and cashmere micron by $3.4-$ 10.0\% between 1998 and 2008 [5]. This trend was not the case for Gobi Gurvan Saikhan and Uuliin Bor breeds which originated from Russian exotic goat breeds [6]. The increased micron threatened the sustainable cashmere production by having a direct increase of unqualified cashmere from $18 \%$ to $30 \%$ in 2016 [3]. First scientific documentations of Mongolian indigenous goats were made by Russian researchers between the 1930s and 1950s [6]. From 1958 onwards, attempts were made to improve the cashmere yield of indigenous goats by importing Pri Don and Gorno Altai breeds from Soviet Union [7], [8]. Russian Pri Don breed was used to bring out the very first cashmere goat breed 'Gobi Gurvan Saikhan' in 1971. Between 1971 and 1991 a total of six goat breeds, strains and lines were registered nationally [9]. After some pause, between 2015 and 2018 additional six goat breeds, strains and lines were registered to make a total of 12 goat breeds and strains as of 2019 [9], [10]. Only 1.9 million out of 25.6 million goats were considered to be of pure breeds and improved local breeds or strains and their crossbreeds with indigenous goats [11]. 
Among registered 12 goat breeds and strains, three of them had originated by crossbreeding with Russian exotic breeds from Don and Gorna Altay (namely; Gobi Gurvan Saikhan, Uuliin Bor, Onjuul breeding group), and the rest were developed indigenously into breeds or strains emphasizing region-specific origin. Breeds or strains rooted from local goats are Bayandelgeriin Ulaan, Ulgiin Ulaan, Zawkhan Buural, Zalaa-jinstiin Tsagaan, Altain Ulaan, Bumbuguriin Ulaan, Erchmiin Khar and 'Mongol' goat breed [12] [8]. However, 'Mongol' goat breed definition states that all goat populations distributed throughout the country with a variety of phenotypic characterization including all above mentioned locally-derived breeds called 'khewshil' or 'forms of breeds or strains' belong to this 'Mongol goat breed' [8] [9]. In terms of genetic structure, Mongolian goat breeds/strains show little differentiation and suggested to be a homogenous population [13] [14] [15].

Reflecting the economic benefit from goats, the number of goats in Mongolia has been increasing

\section{Materials and methodologies}

\section{Description of study area}

The study was conducted in western region of Mongolia in three locations (soums); Ulgii soum Uvs province, Bayan-Uul soum Gobi-Altai province and Erdeneburen soum Khovd province. Ulgii soum is located at geographical point of $48^{\circ} 43^{\prime \prime} 20^{\prime}$. N, $92^{\circ} 13^{\prime \prime} 15^{\prime}$.E and lifted up approximately $1590 \mathrm{~m}$ above sea level. It has total of 2347 population, of which 1841 are herders [18]. 'Ulgii Red' goat was first registered as a strain in 1996 [8] and in 2018 this goat breed was registered as a 'breed' and had of 74000 population [10]. Erdeneburen soum is located at $48^{\circ} 05^{\prime \prime} . \mathrm{N}, 91^{\circ} 38^{\prime \prime} . \mathrm{E}$, at $1250 \mathrm{~m}$ above sea level. Population of 2378, of which 1840 live in the countryside. This soum has no known goat breed but in Altai soum (400km from Erdeneburen soum) of Khovd province, 'Altai Red' goat strain has been kept since 1976 [8]. In 2016 this goat strain registered as a breed [9]. Bayan-Uul soum is located at $46^{\circ} 99^{\prime \prime} 49^{\prime}$.N, $95^{\circ} 19^{\prime \prime} 80^{\prime}$.E, $1850 \mathrm{~m}$ above sea level. There are total of 3079 villagers of which 2094 are herders. There were no specific goat strains or breeds in this province.

Collection of body characteristics or morphological characterization

We recorded body measurements from 608 cashmere goats for the morphological characterization. However, castrated goats and over 5 years of age goats were excluded from data steadily for the last few decades and it has been accounting for more than 40 percent among the five types of livestock species since 2002 [11]. This raised concern about the goat's destructive influence on natural pasture. Some researchers suggested that goats had a three-times higher destructive effect on pasture [16].

There are some successful practices of communitybased breeding programs (CBBP) which aims to implement effective breeding strategies in low input systems [17]. The current situation of goat management practice in Mongolia is that herders mainly overpopulate animals to adjust with the market demand. It clearly indicates that there is a need to develop and implement adequate breeding programs with clear 'objectives' to improve the productivity and quality of a product. One of the very first steps is to assess the current performance traits of local goats where objective breeding is needed the most. This study aims to describe the current phenotypic and cashmere characteristics of cashmere goats in Western Mongolia.

analysis to balance age and sex composition of studied populations. Each goat was identified by its sex and age and they were calculated based on dentition. We classified all the cashmere goats into two age groups based on their dentition; the first group (1- 2 years), the second group (3-4 years). Qualitative data (coat color, ear type, head profile and horn orientation and presence) and quantitative data (body weight, cashmere diameter, cashmere length, raw cashmere yield and linear body measurements such as body length, height of withers, height of rump, body length, chest girth and chest depth) were measured on the goats. Total samples were collected from 608 goats including 300 females and 308 males. 256, 154 and 198 goats were from Bayan-Uul, Erdeneburen and Ulgii soums.

\section{Collection of body measurements and cashmere characters}

Live body weight, other linear body measurements, cashmere length and its yield for each goat were measured using measuring tape and weigh for 608 goats in the sampling sites. The cashmere hair samples were analyzed via microscopic measurement (cashmere length and fineness measured in microns and $\mathrm{cm}$ ) at the laboratory of Cashmere Quality, Research Institute of Animal Husbandry, Ulaanbaatar. 


\section{Statistical analysis}

Prior to main analysis, Shapiro test and Q-Q normality plots were used to examine the distribution of data to check if data are normally distributed. For normally distributed data, least squares mean and statistical differences between quantitative variables were analyzed using linear

The statistical model fitted was:

$\mathrm{Y}_{\mathrm{ijkl}}=\mu+\mathrm{A}_{\mathrm{i}}+\mathrm{B}_{\mathrm{j}}+\mathrm{C}_{\mathrm{k}}+(\mathrm{A} \times \mathrm{B})_{\mathrm{ij}}+(\mathrm{A} \times \mathrm{C})_{\mathrm{ik}}+(\mathrm{B} \mathrm{x}$

$C)_{j k}+(A \times B \times C)_{i j k}+e_{i j k l}$

Where:

$\mathrm{Y}_{\mathrm{ijkl}}=$ The observation on body weight, body length, height of withers, height of rump, body length, chest girth, chest depth, cashmere diameter, cashmere length and raw cashmere yield

$\mu=$ the overall mean;

$\mathrm{A}_{\mathrm{i}}=$ the fixed effect of age ( $\mathrm{i}=1,2$ and 3 to represent 1-2 years, 3-4 years and 5-6 years, respectively)

\section{Results and Discussion}

\section{Quantitative traits}

All of the goats had straight head profile. Physical body characters of cashmere goats are shown in Table 1. Different coat color types were observed in Erdeneburen and Bayan-Uul soums. Black coat color was predominant colour in Erdeneburen and Bayan-Uul soums with the proportion of 46 to $47 \%$ followed by red (28 to 29\%) and mixed colours (15 to $22 \%$ ). However, all of the goats had red coat color in Ulgii soum. Coat colour of Mongolian indigenous goat was stated to be diverse having more than ten widely distributed colours, among them grey, black, white, and red coat colours were predominant [6]. During 1940s Goroshenko recorded that most of indigenous goats in different regions were in grey model $(\mathrm{lm})$ function in $\mathrm{R}$ Studio. Sex, age and locations of the goats were fitted as independent variables while body weight, linear body measurements, cashmere characteristics were set as dependent variables. Tukey-test was used to compare the least square means (LSM) using 0.05 level of significance.

$B$ = the fixed effect of sex $(j=$ male and female $)$

$\mathrm{C}_{\mathrm{k}}=$ the fixed effect of location $(\mathrm{k}=$ Ulgii, Erdeneburen and Bayan-Uul)

$(\mathrm{A} \times \mathrm{B})_{\mathrm{ij}}=$ the interaction effect of age with sex

$(A \times C)_{i k}=$ the interaction effect of age with location

$(B \times C)_{j k}=$ the interaction effect of sex with location $(\mathrm{A} \times \mathrm{B} \times \mathrm{C})_{\mathrm{ijk}}=$ the interaction effect of sex with age with location

$e_{\mathrm{j} j \mathrm{kl}}=$ the effect of random error.

(up to $59.6 \%$ in eastern, 31.1-68.8\% in southern or gobi, 43.3-88.0\% in northern region of the country). After breeding with Russian exotic breeds goat coat colour turned mostly into red and black [6]. By 2004, goat coat colour's proportion was $39.4 \%, 43.3 \%$, $11.0 \%$ and $6.3 \%$ for black, red, white and grey, respectively [6]. Coat colour change could be caused either by the breeding with Russian 'cashmere goat' breeds [6], [8] or by the higher price for the lighter cashmere [19]. As of 2016, all registered goat breeds and strains mostly have coat colour of red $(36.4 \%)$, black (36.4\%) and white (18.2\%) [9]. All goats had back horn orientation $(100 \%)$ and $99.8-99.9 \%$ of goats had horns and $0.1-0.5 \%$ of goats had rudimentary horn.

Physical body characters of cashmere goat populations in different locations

\begin{tabular}{llccc}
\hline Physical body characters & \multicolumn{1}{c}{ Variables } & Erdeneburen $(\%)$ & Ulgii (\%) & Bayan-Uul (\%) \\
\hline Head profile & Straight & 100 & 100 & 100 \\
Ear type & Horizontal & 100 & 100 & 100 \\
& White & 7 & & 4 \\
\multirow{5}{*}{ Coat color } & Black & 47 & & 46 \\
& Brown & 0 & 0 & 0 \\
& Red & 29 & 100 & 28 \\
\multirow{4}{*}{ Horn orientation and } & Grey & 7 & & 22 \\
presence & Combinations of colors & 15 & & 100 \\
& Back oriented & 100 & 100 & 99.9 \\
\hline
\end{tabular}


Least square means (LSM) and standard deviation $( \pm$ SE) of live weight $(\mathrm{kg})$,

Table 2

linear body measurements $(\mathrm{cm})$ and cashmere characters for the cashmere goat populations

\begin{tabular}{|c|c|c|c|c|c|c|c|c|c|c|c|c|c|c|c|c|c|c|}
\hline \multirow[t]{2}{*}{ Variables } & \multicolumn{2}{|c|}{ LBW (kg) } & \multicolumn{2}{|c|}{$\mathrm{HW}(\mathrm{cm})$} & \multicolumn{2}{|c|}{$\mathrm{ChG}(\mathrm{cm})$} & \multicolumn{2}{|c|}{$\mathrm{HR}(\mathrm{cm})$} & \multicolumn{2}{|c|}{$\mathrm{BL}(\mathrm{cm})$} & \multicolumn{2}{|c|}{$\mathrm{ChD}(\mathrm{cm})$} & \multicolumn{2}{|c|}{$\operatorname{CshD}(\mu \mathrm{m})$} & \multicolumn{2}{|c|}{$\mathrm{LCsh}(\mathrm{cm})$} & \multicolumn{2}{|c|}{ RCSHY (g) } \\
\hline & $1 \mathrm{sm}$ & SE & lsm & $\mathrm{SE}$ & Lsm & SE & Lsm & SE & Lsm & $\mathrm{SE}$ & $1 \mathrm{sm}$ & SE & $1 \mathrm{sm}$ & SE & $1 \mathrm{sm}$ & $\mathrm{SE}$ & $1 \mathrm{sm}$ & SE \\
\hline Overall mean & 28.15 & 7.67 & 59.01 & 4.33 & 73.14 & 6.59 & 60.92 & 4.42 & 62.10 & 5.87 & 25.96 & 2.66 & 16.44 & 0.54 & 4.19 & 2.31 & 441.69 & 77.15 \\
\hline $\begin{array}{l}\text { CV } \\
\text { Age }\end{array}$ & $\begin{array}{l}17.14 \\
* * *\end{array}$ & 5.43 & $\begin{array}{l}5.72 \\
* * *\end{array}$ & 1.40 & $\begin{array}{l}6.62 \\
* *\end{array}$ & 2.15 & $\begin{array}{l}5.55 \\
* * *\end{array}$ & 1.39 & $\begin{array}{l}7.02 \\
* * *\end{array}$ & 2.25 & $\begin{array}{l}8.85 \\
* * *\end{array}$ & 2.38 & $\begin{array}{l}3.14 \\
* * *\end{array}$ & 1.11 & 12.84 & 3.73 & $\begin{array}{l}14.48 \\
* * *\end{array}$ & 6.33 \\
\hline $1-2$ & 21.9 & $0.74^{\mathrm{b}}$ & 54.3 & $0.4^{\mathrm{a}}$ & 65.0 & $4.10^{\mathrm{a}}$ & 56.0 & $0.5^{\mathrm{a}}$ & 55.3 & $0.65^{\mathrm{a}}$ & 23.1 & $0.41^{\mathrm{a}}$ & 15.9 & $0.07^{\mathrm{a}}$ & 5.0 & $0.36^{\mathrm{a}}$ & 407 & $8.68^{a}$ \\
\hline $\begin{array}{l}3-4 \\
\text { Sex }\end{array}$ & $\begin{array}{l}28.6 \\
* * *\end{array}$ & $0.39^{\mathrm{a}}$ & $\begin{array}{l}61.2 \\
* * *\end{array}$ & $0.2^{b}$ & $\begin{array}{l}78.7 \\
*\end{array}$ & $1.75^{b}$ & $\begin{array}{l}63.3 \\
* * *\end{array}$ & $0.21^{\mathrm{b}}$ & $\begin{array}{l}64.8 \\
* * *\end{array}$ & $0.79^{b}$ & $\begin{array}{l}27.4 \\
* * *\end{array}$ & $0.17^{b}$ & 16.76 & $0.03^{b}$ & $\begin{array}{l}4.72 \\
* *\end{array}$ & $0.15^{\mathrm{a}}$ & $\begin{array}{l}465 \\
* * *\end{array}$ & $3.71^{\mathrm{b}}$ \\
\hline Buck & 33.5 & & 59.8 & $0.4^{\mathrm{a}}$ & 74.4 & $3.42^{\mathrm{a}}$ & 61.3 & & 61.6 & & 26.3 & & 16 & $0.06^{\mathrm{a}}$ & 4.31 & $0.30^{\mathrm{a}}$ & 465 & $7.25^{\mathrm{a}}$ \\
\hline Female & 24.8 & $0.46^{\mathrm{b}}$ & 55.7 & $0.34^{\mathrm{b}}$ & 69.2 & $2.99^{b}$ & 58.0 & $0.57^{b}$ & 58.5 & $0.477^{\mathrm{b}}$ & 24.2 & $0.30^{\mathrm{b}}$ & 16.3 & $0.05^{\mathrm{a}}$ & 5.41 & $0.26^{\mathrm{b}}$ & 407 & $6.33^{\mathrm{b}}$ \\
\hline Location & $* * *$ & & $*$ & & & & & & $* * *$ & & $* * *$ & & & & $* * *$ & & $* * *$ & \\
\hline Erdene & 27.3 & $0.58^{a}$ & 55.5 & $0.43^{b}$ & 70.4 & $3.54^{\mathrm{a}}$ & 57.4 & $0.42^{\mathrm{a}}$ & 58.2 & $0.56^{\mathrm{a}}$ & 24.1 & $0.35^{b}$ & 16.1 & $0.06^{\mathrm{a}}$ & 4.79 & $0.31^{\mathrm{a}}$ & 425 & $7.49^{\mathrm{a}}$ \\
\hline Ulgii & 31.5 & $0.57^{b}$ & 58.6 & $0.42^{\mathrm{b}}$ & 72.7 & $3.54^{\mathrm{a}}$ & 60.3 & $0.44^{\mathrm{a}}$ & 63.6 & $0.58^{b}$ & 26.2 & $0.36^{\mathrm{a}}$ & 16.2 & $0.06^{\mathrm{a}}$ & 3.84 & $0.32^{\mathrm{b}}$ & 461 & $7.77^{\mathrm{b}}$ \\
\hline $\begin{array}{l}\text { Bayan-Uul } \\
\text { Age*Sex }\end{array}$ & $\begin{array}{l}28.6 \\
* * *\end{array}$ & $0.61^{\mathrm{a}}$ & 59.1 & $0.54^{\mathrm{a}}$ & 72.3 & $4.61^{\mathrm{a}}$ & 61.2 & $0.55^{\mathrm{a}}$ & $\begin{array}{l}58.4 \\
* * *\end{array}$ & $0.73^{\mathrm{b}}$ & 25.4 & $0.46^{\mathrm{b}}$ & 16.6 & $0.08^{\mathrm{a}}$ & $\begin{array}{l}5.95 \\
*\end{array}$ & $0.41^{\mathrm{a}}$ & $\begin{array}{l}423 \\
* * *\end{array}$ & $9.75^{\mathrm{a}}$ \\
\hline $1 *$ buck & 24.5 & $1.15^{\mathrm{a}}$ & 56.5 & $0.74^{\mathrm{a}}$ & 67.5 & $6.42^{\mathrm{a}}$ & 58.0 & 0.10 & 56.2 & & 24.1 & $0.64^{\mathrm{a}}$ & 15.9 & $0.11^{\mathrm{a}}$ & 4.12 & $0.56^{\mathrm{a}}$ & 416 & $13.5^{\mathrm{a}}$ \\
\hline $2 *$ buck & 31.4 & $0.55^{\mathrm{b}}$ & 63.0 & $0.3^{\mathrm{a}}$ & 81.3 & $2.49^{\mathrm{a}}$ & 64.6 & $0.3^{\mathrm{a}}$ & 67.1 & $0.39^{b}$ & 28.5 & $0.25^{\mathrm{a}}$ & 16.7 & $0.04^{\mathrm{a}}$ & 4.51 & $0.22^{\mathrm{b}}$ & 514 & $5.27^{\mathrm{b}}$ \\
\hline $1 *$ Female & 19.3 & $1.00^{\mathrm{a}}$ & 52.0 & $0.64^{\mathrm{a}}$ & 62.5 & $5.52^{\mathrm{a}}$ & 54.0 & $0.65^{\mathrm{a}}$ & 54.4 & $0.88^{a}$ & 22.0 & $0.55^{\mathrm{a}}$ & 16.0 & $0.1^{\mathrm{a}}$ & 5.88 & $0.48^{a}$ & 398 & $11.68^{\mathrm{a}}$ \\
\hline $2 *$ Female & 25.7 & $0.56^{\mathrm{b}}$ & 59.3 & $0.28^{\mathrm{a}}$ & 76.0 & $2.46^{\mathrm{a}}$ & 61.9 & $0.3^{\mathrm{a}}$ & 62.5 & $0.4^{\mathrm{b}}$ & 26.3 & $0.24^{\mathrm{a}}$ & 16.6 & $0.04^{\mathrm{a}}$ & 4.93 & $0.22^{\mathrm{a}}$ & 416 & $5.20^{\mathrm{b}}$ \\
\hline
\end{tabular}

Signif. codes: 0 ‘***’ 0.001 '**' 0.01 “*' 0.05 ‘' 0.1 ، ' 1

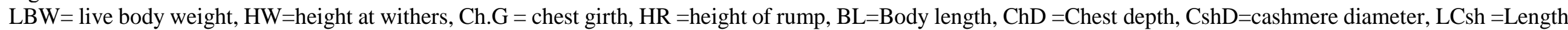
of cashmere, RCSHY= raw cashmere yield 
Live body weight and body linear measurements: Least square mean and standard errors for sex, age, location effects on live body weight, linear body measurements and, cashmere characters are presented in Table 2. Body linear measurements and live weight are widely taken when assessing the productiveness of farm animals or defining the general characterization of particular populations [9] [20] [21]. Values of live body weight, height at withers, height of rump, body length, and chest depth were significantly $(p<0.001)$ differed among age, sex groups, and locations. There were also significant differences $(p<0.01)$ of chest girth among age groups and between sex $(p<0.05)$. Live body weight and body length were significantly different for sex*age classes. Body weight was significant $(p<0.001)$ between males and females. The live body weight, body length, chest depth showed significant variations $(\mathrm{p}<0.001)$ for the locations. For the Ulgii soum, live body weight, body length, chest depth and raw cashmere yield were significantly higher than the other two soums. This could be because of Ulgii Red breed has a considerably longer breeding history as a strain than other two indigenous populations [9] [22]. The 'Altai Ulaan' breed is one of the cashmere goat breeds in Western Mongolia and the closest to the study sites geographically. We compared the body linear measurement of this breed with our results to see differences among populations and closeness to the registered breed. It appeared that goats in Erdeneburen soum showed the closest values while the other two soums showed greater values in terms of live body weight and body linear measurements.

\section{Cashmere characteristics:}

Cashmere characters were significantly $(\mathrm{p}<0.001)$ affected by age and sex. The diameter of cashmere and raw cashmere yield were significantly $(\mathrm{p}<0.001)$ differed among age, sex groups, and locations. Length of cashmere and raw cashmere yield showed

\section{Conclusion}

Phenotypic traits (body weight, linear body measurements and, cashmere characteristics) of Mongolian goat populations were characterized by the effect of sex, age, location, and sex*age effects. By the effects of location, age, there were significant

\section{Acknowledgements}

The authors are thankful to the participated herders and local administrative animal breeding specialists to collect the data. We are also greatly appreciate to significant variations $(\mathrm{p}<0.001)$ for the locations. Overall cashmere diameter was $16.44 \mu \mathrm{m}$ with no significant difference between the three populations. This value falls under the 'first' grade according to the quality standard of cashmere (15.51-16.50 $\mu \mathrm{m}$ [23]) after 'fine' quality which covers the range of 13.0-15.5 $\mu \mathrm{m}$. Between 2001 and 2003, cashmere diameter was assessed nationwide. The results showed an average of $16.55 \mu \mathrm{m}$ in the eastern region, $16.7 \mu \mathrm{m}$ in the western region, $16.71 \mu \mathrm{m}$ in the khangai region and, $16.79 \mu \mathrm{m}$ in the central region [24]. Ulgii Red breed has some historical data on cashmere characteristics. In 1992 Ulgii Red had a cashmere diameter of 14.7 for the adult buck, 14.6 for the young buck, 14.5 for adult females and, 14.1 for young females. In 1998, the flock average micron size was $14.85 \mu \mathrm{m}$, and 17.5 in 2008 [8]. Our results showed at $16.2 \mu \mathrm{m}$ at flock level. This slightly lessened micron size, when compared with data of 2008 , could be due to the age of studied goats (1-4) that we excluded all castrated males and 5-year-olds or older goats from the analysis. In terms of cashmere length goats in Bayan-Uul soum were significantly $(p<0.001)$ longer than the other two populations. Cashmere characterization study on Gobi Gurvan Saikhan and Uuliin Bor goat breeds showed that cashmere length is affected by age [6]. The older goat gets the longer cashmere length measures. However, our study result contradicts their results having lower value in older goats. Cashmere length Ulgii Red goat had the shortest value $(3.84 \mathrm{~cm})$ for cashmere length. Previous studies [8] noted that the cashmere length of Ulgii red strain was $5.75 \mathrm{~cm}$ in 1992 and $4.78 \mathrm{~cm}$ in 2011 . It could be said that there was a decrease in the cashmere length of Ulgii Red goat over the years. However, our data appear incompetent to compare with flock average values of quantitative traits since we excluded all castrated and 5-year-olds or older goats for the purpose of concentrating on breeding animals.

variations on the live body weight, the linear body measurements, the cashmere characteristics.

Live body weight, body length, chest depth, raw cashmere yield could be considered as the selection criteria of breeding for meat and cashmere production.

Johann Sölkner, the University Professor, who advised on this study at the University of Natural Resources and Life Sciences in Vienna. 


\section{References}

[1] N. Nyamsuren, Mongolian Cashmere: Economic, Marketing and Strategy. Ulaanbaatar, 2002.

[2] M. Meurs, A. Amartuvshin, and O. Banzragch, "Livestock Income of Mongolian Herders: A Path to Rural Prosperity," Nomadic Peoples, vol. 21, pp. 87-110, Jan. 2017, http://doi: 10.3197/np.2017.210105.

[3] W. Danforth, "Export Expansion and Goat Growth: Cashmere Quality Decline Threatens Industry's Gains," Mongolia International Capital Cooperation, Ulaanbaatar, Market report, 2017. Accessed: Feb. 05, 2018. [Online]. Available: https://frontcap.com/wpcontent/uploads/2017/02/Mongolias-CashmereReport-February-2017.pdf.

[4] Д. Цэрэнсоном, “Продуктивность помесных коз, разводимых в южногобийском аймаке," Труды научно-исследовательского института животноводства, по. 14, 1966.

[5] B. Mandakh and B. Narantuya, "Results of cashmere goat breeding and selection," presented at the Goats: Ecological and Economic concerns, Ulaanbaatar, 2009.

[6] B. Mandakh, Y. Zagdsuren, B. Narantuya, G. Suvdaa, D. Dungu, and L. Narantuya, Goat study - 50 years. Ulaanbaatar: Research Institute of Animal Husbandry, 2011.

[7] Z. Gonchigjav, R. Javzmaa, and C. Unenburen, Livestock of Mongolia. Ulaanbaatar, 1980.

[8] Y. Zagdsuren, Study of Mongolian goats for 80 years. Ulaanbaatar: Selenge Press, 2011.

[9] D. Samdanjamts, B. Minjigdorj, and G. Badamkhand, Livestock Breeds in Mongolia. Ulaanbaatar, 2016.

[10] B. Manaljav and N. Baatar, "Cashmere yield and quality characteristics of Ulgii Red goat and the factors influencing to its performance," Mongolian University of Life Sciences, Ulaanbaatar, 2019.

[11] National Statistics Office of Mongolia, "Agricultural Sector." Government of Mongolia, 2017, [Online]. Available: http://1212.mn/stat.aspx?LIST_ID=976_L10_1.

[12] N. Nadmid and B. Altantsetseg, Handbook for cashmere goat herders. Ulaanbaatar: Initiative for Development of Gobi Region, 2000.

[13] D. Nyamsamba, K. Nomura, Nozawa, M. Yokohama, K. Y. Zagdsuren, and T. Amano,
"Genetic relationship among Mongolian native goat populations estimated by blood protein polymorphism," Small Rumin. Res., vol. 47, pp. 171-181, 2003.

[14] H. Takahashi et al., "Genetic Structure of Mongolian Goat Populations Using Microsatellite Loci Analysis," Asian-Australas. J. Anim. Sci., vol. 21, no. 7, pp. 947-953, Jul. 2008, doi: 10.5713/ajas.2008.70285.

[15] S. Bolormaa, A. Ruvinsky, and B. Mandakh, "Genetic structure and differentiations among some breed and strains of goat populations in Mongolia," Mongolian Journal of Agricultural Science, vol. 10, no. 01, pp. 71-77, 2013.

[16] Research Institute of Animal Husbandry, "'Pasture utilization and dynamics 2005-2007' project report," Ulaanbaatar, 2008.

[17] M. Wurzinger, J. Sölkner, and L. Iniguez, "Important aspects and limitations in considering community-based breeding programs for low-input smallholder livestock systems," Small Rumin. Res. SMALL Rumin. RES, vol. 98, pp. 170-175, Jun. 2011, doi: 10.1016/j.smallrumres.2011.03.035.

[18] National Statistics Office of Mongolia, "Uvs province." 2017.

[19] Mercy Corps International, "Cashmere Market: Processing companies' requirements and trends on raw cashmere." Mercy Corps International, 2004.

[20] E. Chacyn, F. Macedo, F. Velozquez, S. R. Paiva, E. Pineda, and C. McManus, "Morphological measurements and body indices for Cuban Creole goats and their crossbreds," Soc. Bras. Zootech., vol. 40, no. 8, pp. 1671-1679, 2011.

[21] D. Altangerel, Z. Tonya, and D. Bataa, Altain ulaan breeding-group goat. Ulaanbaatar: Mongolian State University of Agriculture, 2014.

[22] B. Manaljav and N. Baatar, "Cashmere yield and quality characteristics of Ulgii Red goat and the factors influencing to its performance," Mongolian University of Life Sciences, Ulaanbaatar, 2019.

[23] Mongolian Agency for Standardization and Metrology, "MNS:2008 Cashmere Quality Standard." 2008.

[24] "Mongolia - German joint project 2+2," Institute of Nekhmel, Mongolian Uviversity of Science and Technology, Ulaanbaatar, 2004. 